\title{
TRANSESTERIFIKASI PARSIAL MINYAK KELAPA SAWIT DENGAN ETANOL PADA PEMBUATAN DIGLISERIDA SEBAGAI AGEN PENGEMULSI
}

\author{
Rita Arbianti*, Tania Surya Utami, Heri Hermansyah, \\ Ira Setiawati, dan Eki Listya Rini \\ Departemen Teknik Kimia, Fakultas Teknik, Universitas Indonesia \\ Kampus Baru UI Depok 16424 \\ Email: arbianti@che.ui.ac.id
}

\begin{abstract}
Abstrak
Laju pertumbuhan produksi minyak kelapa sawit yang tinggi mendorong perlunya diversifikasi minyak kelapa sawit menjadi produk lain dengan nilai ekonomis tinggi, salah satunya adalah sebagai agen pengemulsi. Agen pengemulsi yang dibuat dari minyak nabati bersifat biodegradable, sehingga tidak mencemari lingkungan, dan kesinambungan pengadaannya terjamin karena berasal dari sumber daya alam yang dapat diperbaharui. Dalam produksi agen pengemulsi berbahan baku minyak kelapa sawit, reaksi transesterifikasi merupakan tahapan awal yang akan mempengaruhi kualitas produk yang dihasilkan. Penelitian ini bertujuan untuk mengkaji kondisi transesterifikasi parsial minyak kelapa sawit. Proses transesterifikasi menggunakan $\mathrm{NaOH}$ sebagai katalis dan minyak kelapa sawit. Variabel yang divariasikan untuk mengkaji pengaruhnya terhadap kinerja produk digliserida yang dihasilkan adalah persen berat katalis $\mathrm{NaOH}(0,1,0,2,0,3$, dan 0,4 \{mol $\mathrm{NaOH} / \mathrm{kg}$ minyak\}), suhu transesterifikasi $\left(40,50,60\right.$, dan $\left.70{ }^{\circ} \mathrm{C}\right)$, waktu transesterifikasi $(15,20$, 25 , dan 30 menit), dan rasio reaktan (1:3, 1:4, 1:5, dan 1:6 (mol minyak:mol etanol\}). Produk digliserida diuji kemampuannya sebagai agen pengemulsi dalam menurunkan tegangan permukaan air, serta dalam menjaga kestabilan emulsi minyak/air. Hasil penelitian menunjukkan bahwa produk digliserida memiliki kemampuan menurunkan tegangan permukaan air optimum pada persen berat katalis $\mathrm{NaOH}$ sebesar $0,3 \mathrm{~mol} \mathrm{NaOH} / \mathrm{kg}$ minyak, suhu transesterifikasi $50{ }^{\circ} \mathrm{C}$, waktu reaksi 30 menit, dan rasio reaktan 1:6 mol minyak:mol etanol.
\end{abstract}

Kata kunci: agen pengemulsi, digliserida, minyak kelapa sawit, $\mathrm{NaOH}$, transesterifikasi

\begin{abstract}
High growth rate of palm oil production has encouraged palm diversification to be other products with higher economic value, which one of them is emulsifier. Emulsifier based on vegetable oil is biodegradable so they won't soil our environment. Besides that, its continuity of provisioning is also ensured because it is a renewable resource. In production of emulsifier based on palm oil, transesterification reaction is a first step that influences quality of emulsifier produced. The aim of this research is to determine the condition of palm oil partial transesterification. The partial transesterification process used $\mathrm{NaOH}$ as catalyst and palm oil. Variables varied were percent weight of $\mathrm{NaOH}(0.1,0.2,0.3$, and 0.4 mole $\mathrm{NaOH} / \mathrm{kg}$ oil\}), transesterification temperature $(40,50$, 60 , and $\left.70^{\circ} \mathrm{C}\right)$, reaction time $(15,20,25$, and 30 minutes $)$, ratio of reactant $(1: 3,1: 4,1: 5$, and 1:6\{mole oil:mole ethanol\}), to discuss these effects to diglyceride product activity. Diglyceride product was tested by its ability as emulsifier in system stability of oil/water emulsion and to decrease surface tension of water. Result of this research indicated that diglyceride product has optimum declining of surface tension of water on percent weight of $\mathrm{NaOH}$ of $0.3 \mathrm{~mole} \mathrm{NaOH} / \mathrm{kg}$ oil, transesterification temperature of $50{ }^{\circ} \mathrm{C}$, reaction time of 30 minutes, and ratio of reactant of $1: 6$ mole oil: mole ethanol.
\end{abstract}

Keywords: diglyceride, emulsifier, $\mathrm{NaOH}$, palm oil, transesterification.

*korespondensi 


\section{Pendahuluan}

Produk pengolahan CPO di Indonesia yang memiliki nilai ekonomis masih terbatas pada minyak goreng dan produk-produk oleokimia seperti asam lemak, fatty alcohol, sabun, metil ester, dan stearin. Berdasarkan Oil World and Reuter, industri oleokimia dasar ini baru mampu menyumbangkan produksi sebesar 3,6\% dari produksi oleokimia dunia (Goenadi, 2005). Padahal, produk oleokimia tersebut memiliki nilai tambah yang cukup besar dibandingkan dengan produk pengolahan minyak kelapa sawit lainnya, yaitu berkisar 20-600\% dari nilai mentahnya (Goenadi, 2005). Oleh karena itu, diperlukan upaya diversifikasi minyak kelapa sawit yang lebih beragam untuk meningkatkan nilai ekonomisnya.

Salah satu produk oleokimia yang bernilai ekonomis tinggi adalah agen pengemulsi. Agen pengemulsi umumnya disintesis dari minyak bumi (petrokimia) maupun minyak hewani. Kebutuhan akan agen pengemulsi pada produk pangan, kecantikan maupun kesehatan yang berbasis emulsi pun semakin meningkat. Pengadaan agen pengemulsi berbahan baku nabati telah dikembangkan. Salah satu produknya adalah Lisofosfatidilkolin (LPC) atau dikenal dengan nama dagang lesitin. Lesitin telah memperoleh GRAS (Generally Recognised As Safe)-status dari FDA. Lesitin bersifat mudah terurai secara biologi (biodegradable) sehingga lebih aman untuk dikonsumsi dan kesinambungan pengadaannya terjamin karena dihasilkan dari sumber daya alam yang dapat diperbarui. Maka, senyawa ini dapat digunakan sebagai agen pengemulsi untuk produk pangan, kecantikan (kosmetika), hingga kedokteran.

Agen pengemulsi didefinisikan sebagai senyawa yang mempunyai aktivitas permukaan (surface-active agents) sehingga dapat menurunkan tegangan permukaan (surface tension) antara udara-cairan dan cairan-cairan yang terdapat dalam suatu sistem makanan. Kemampuannya menurunkan tegangan permukaan menjadi hal yang menarik karena agen pengemulsi memiliki keunikan struktur kimia yang mampu menyatukan dua senyawa berbeda polaritasnya. Tingkat penurunan tegangan permukaan oleh senyawa pengemulsi berkisar antara 50 dyne/cm hingga kurang dari 10 dyne/cm jika digunakan pada konsentrasi lebih kecil dari 0,2\% (Noureddini dan Zhu, 1997).

Minyak nabati yang sering digunakan sebagai bahan baku produk oleokimia adalah minyak kelapa sawit karena memiliki distribusi rantai karbon yang sesuai untuk berbagai jenis produk yang akan dihasilkan, sehingga dapat menghasilkan produk yang cukup memuaskan (Nakamura, 2001). Komponen penyusun utama dari minyak kelapa sawit yaitu trigliserida. Trigliserida merupakan ester dari gliserol dengan tiga molekul asam lemak (Ketaren, 1986). Untuk memperoleh bahan agen pengemulsi, trigliserida tersebut direaksikan hingga menjadi monogliserida maupun digliserida. Lesitin merupakan agen pengemulsi yang berbahan baku digliserida. Hal ini berarti bahwa dengan mengembangkan agen pengemulsi lesitin yang berbahan baku CPO merupakan salah satu jalan diversifikasi CPO, yang sekaligus berfungsi untuk meningkatkan nilai ekonomisnya.

Digliserida diperlukan untuk pembuatan lesitin. Dalam hal ini, kondisi reaksi transesterifikasi parsial memegang peranan yang sangat penting karena proses pembuatan digliserida berlangsung melalui reaksi transesterifikasi. Hal-hal yang dapat mempengaruhi reaksi transesterifikasi antara lain persen berat katalis dan suhu reaksi. Kondisi tersebut jelas akan menentukan kuantitas dan kualitas digliserida yang dihasilkan, yang selanjutnya akan digunakan dalam pembuatan senyawa Lesitin.

May (2004) melaporkan pengaruh parameter reaksi transesterifikasi parsial minyak sawit mentah menjadi metil ester. Parameter reaksi tersebut meliputi katalis basa yang digunakan, keasaman CPO (kandungan asam lemak bebas), kecepatan pengadukan, konsentrasi katalis basa, konsentrasi alkohol (metanol), temperatur reaksi, dan kandungan air dalam metanol. Berdasarkan penelitiannya diperoleh bahwa kondisi reaksi optimum dicapai pada rasio mol metanol:minyak ialah 10:1 dengan waktu reaksi 7 menit pada suhu $65,5{ }^{\circ} \mathrm{C}$. Kecepatan reaksi optimal dicapai pada kecepatan pengadukan sebesar 150 rpm dengan jumlah minimum metanol yang dibutuhkan untuk mencapai konversi total adalah 233\% metanol berlebih. Dari penelitian tersebut juga dilaporkan bahwa katalis yang digunakan tidak boleh lebih dari 
0,5 mol/kg minyak karena dapat mengakibatkan solidifikasi campuran reaksi dan pembentukan sabun.

\section{Metodologi}

Penelitian diawali dengan penentuan bilangan asam dan kadar air yang terdapat dalam minyak kelapa sawit. Bilangan asam ditentukan dengan metode titrasi asam basa dan kadar air ditentukan dengan metode penguapan.

Reaksi transesterifikasi parsial dilakukan dengan memasukkan minyak kelapa sawit ke dalam reaktor yang dilengkapi dengan refluks kemudian dimasukkan ke dalam water bath dengan suhu sesuai variasi yang diinginkan. Kemudian, campuran etanol- $\mathrm{NaOH}$ dimasukkan sesuai dengan rasio mol reaktan ke dalam reaktor secara perlahanlahan sambil terus diaduk. Selanjutnya campuran tersebut direaksikan pada kondisi suhu sesuai variasi dengan kecepatan pengaduk listrik sebesar $\pm 100 \mathrm{rpm}$ selama 15 menit. Reaksi ini dilakukan dengan variasi persen berat katalis $\mathrm{NaOH}(0,1,0,2$, $0,3$ dan 0,4 mol $\mathrm{NaOH} / \mathrm{kg}$ minyak $\}$ ), suhu reaksi $\left(40,50,60\right.$, dan $\left.70^{\circ} \mathrm{C}\right)$, waktu reaksi $(15,20,25$ dan 30 menit), dan rasio reaktan $(1: 3,1: 4,1: 5$, dan $1: 6\{$ mol minyak:mol etanol\}).

Setelah reaksi, produk hasil reaksi didiamkan selama semalam dalam labu pemisah dan dilakukan pencucian produk tersebut dengan $\mathrm{H}_{2} \mathrm{SO}_{4}$, aquades, dan $\mathrm{Na}_{2} \mathrm{SO}_{4}$ anhidrat untuk memisahkan EtOH dan katalis $\mathrm{NaOH}$ dari produk. Selanjutnya, dilakukan analisis produk digliserida untuk mengetahui kemampuannya sebagai emulsifier. Analisis dilakukan dengan melihat kemampuan produk dalam menurunkan tegangan permukaan dan menstabilkan emulsi minyak-air.

\section{Hasil dan Pembahasan}

Tujuan dari penentuan bilangan asam dan kadar air dalam minyak adalah untuk mengetahui mutu minyak kelapa sawit yang digunakan, sehingga dapat ditentukan perlu atau tidaknya dilakukan penetralan dan penghilangan kadar air yang ada di dalam minyak kelapa sawit. Besarnya bilangan asam minyak goreng kelapa sawit yang sesuai standar adalah kurang dari 0,5 mg $\mathrm{KOH} /$ gram minyak. Sedangkan, besarnya kadar air yang sesuai standar adalah sebesar
1\% berat (Astri, 2007). Dari hasil penelitian, diperoleh nilai bilangan asam minyak sebesar 0,49 mg KOH/g minyak dan kadar air minyak sebesar 0,09\%. Kedua angka tersebut masih berada di bawah batas maksimum standar sehingga tidak perlu dilakukan penetralan dan penghilangan kadar air dari minyak tersebut.

Sebelum menganalisis produk digliserida hasil reaksi transesterifikasi parsial, dilakukan pengukuran tegangan permukaan air dan uji kestabilan emulsi minyak-air tanpa penambahan produk digliserida. Hasil pengujian tersebut kemudian dibandingkan terhadap hasil pengujian dengan penambahan produk digliserida. Hal ini bertujuan untuk mengetahui kemampuan produk digliserida sebagai agen pengemulsi dalam menurunkan tegangan permukaan air dan mempertahankan kestabilan emulsi. Berdasarkan hasil pengujian, tegangan permukaan air tanpa penambahan produk digliserida sebesar 68 dyne/cm. Uji kestabilan emulsi menunjukkan, tanpa penambahan produk digliserida emulsi minyak-air hanya dapat stabil selama 21,7 detik.

\section{Pengaruh persen berat katalis $\mathrm{NaOH}$}

Gambar 1 menunjukkan kecenderungan bahwa penurunan tegangan permukaan air meningkat seiring dengan meningkatnya persen berat katalis $\mathrm{NaOH}$ yang digunakan. Berdasarkan hasil pengukuran tegangan permukaan tersebut, produk digliserida dengan persen berat katalis $0,3 \mathrm{~mol} \mathrm{NaOH} / \mathrm{kg}$ minyak adalah produk yang mampu menurunkan tegangan permukaan air paling optimum. Hal ini disebabkan dengan bertambahnya katalis

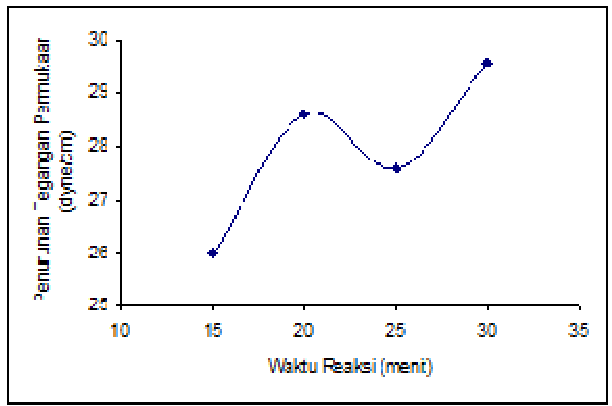

Gambar 1. Pengaruh persen berat katalis $\mathrm{NaOH}$ terhadap penurunan tegangan permukaan air 
akan menyebabkan reaksi semakin cepat atau laju reaksi semakin besar. Dengan waktu reaksi yang sama, laju reaksi yang semakin besar akan menghasilkan produk digliserida yang semakin banyak sehingga memberikan penurunan tegangan permukaan air semakin besar. Pada kondisi tersebut, penambahan produk digliserida dapat menstabilkan emulsi minyak-air selama 42 detik.

\section{Pengaruh suhu reaksi}

Pengaruh suhu reaksi terhadap penurunan tegangan permukaan air setelah ditambahkan produk digliserida dapat dilihat pada Gambar 2. Pada Gambar 2, penurunan tegangan permukaan air menurun seiring dengan semakin tinggi suhu reaksi dan diperoleh titik optimum pada suhu $50{ }^{\circ} \mathrm{C}$, kemudian berkurang pada suhu $60{ }^{\circ} \mathrm{C}$ dan $70{ }^{\circ} \mathrm{C}$. Hal ini disebabkan suhu diatas $60^{\circ} \mathrm{C}$ hampir mendekati titik didih etanol sehingga kemungkinannya etanol sudah menguap sebelum reaksi berjalan sesuai yang diinginkan. Uji kestabilan emulsi menunjukkan bahwa penambahan produk digliserida yang dihasilkan dari reaksi transesterifikasi parsial pada suhu $50^{\circ} \mathrm{C}$ dapat menstabilkan emulsi minyak-air hingga 38 detik.

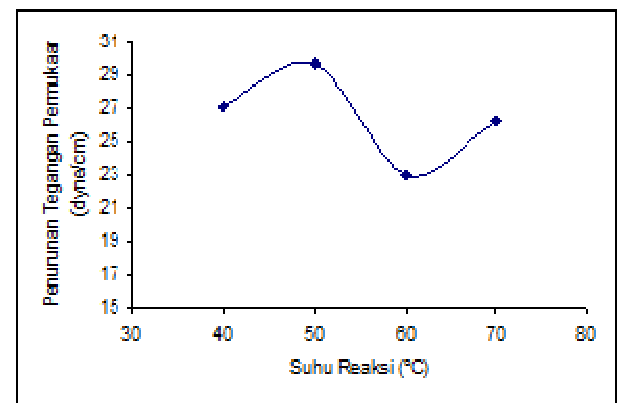

Gambar 2. Pengaruh suhu reaksi transesterifikasi parsial terhadap penurunan tegangan permukaan air

\section{Pengaruh waktu reaksi}

Pengaruh waktu reaksi terhadap penurunan tegangan permukaan air setelah penambahan produk digliserida dapat dilihat pada Gambar 3. Berdasarkan Gambar 3 diketahui bahwa semakin lama waktu reaksi maka penurunan tegangan permukaan air dengan penambahan produk akan semakin meningkat. Hal ini disebabkan produk agen pengemulsi akan semakin banyak dalam waktu reaksi yang semakin lama. Meningkatnya produk agen pengemulsi disebabkan waktu kontak reaktan yang semakin besar akan memberikan reaksi yang lebih sempurna, sehingga produk yang dihasilkan semakin banyak. Pada waktu reaksi yang optimum dalam penelitian ini yaitu 30 menit, penambahan produk digliserida dapat menstabilkan emulsi minyak-air selama 46 detik.

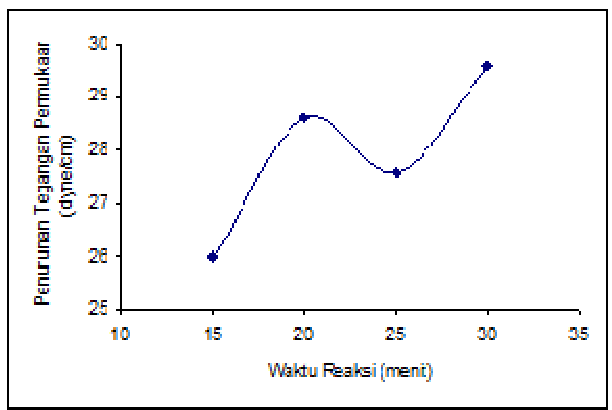

Gambar 3. Pengaruh waktu reaksi transesterifikasi parsial terhadap penurunan tegangan permukaan air

\section{Pengaruh rasio mol reaktan}

Pengaruh rasio mol reaktan terhadap penurunan tegangan permukaan air setelah penambahan produk digliserida dapat dilihat pada Gambar 4 .

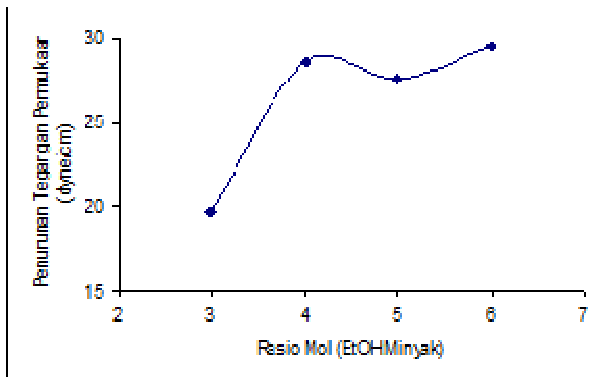

Gambar 4. Pengaruh rasio mol reaktan terhadap penurunan tegangan permukaan air

Berdasarkan Gambar 4 diketahui bahwa semakin besar rasio mol reaktan maka penurunan tegangan permukaan air akan semakin meningkat. Meningkatnya penurunan tegangan air diduga karena semakin besarnya kandungan digliserida dalam produk. Seperti pada pembahasan sebelumnya, bertambahnya kandungan digliserida sebagai produk transesterifikasi, secara teoritis sesuai dengan asas Le 
Chatelier bahwa bertambahnya jumlah mol reaktan akan mendorong reaksi berlangsung ke arah pembentukan produk. Uji kestabilan emulsi menunjukkan bahwa penambahan produk digliserida yang dihasilkan dari reaksi transesterifikasi parsial dengan rasio mol minyak:etanol yaitu 1:6 dapat menstabilkan emulsi minyak-air hingga 46 detik.

Secara umum, produk digliserida hasil reaksi transesterifikasi parsial pada penelitian ini mampu berfungsi sebagai agen pengemulsi. Hal ini dapat diketahui dari kemampuan produk dalam menurunkan tegangan permukaan air. Dari pengujian stabilitas emulsi, sistem emulsi minyak-air yang ditambahkan produk digliserida memiliki kestabilan emulsi yang lebih lama, bahkan hingga 2 kali lebih lama, dibandingkan tanpa penambahan produk.

\section{Kesimpulan}

Produk digliserida menghasilkan penurunan tegangan permukaan air yang semakin meningkat seiring dengan besarnya persen berat katalis $\mathrm{NaOH}$ yang digunakan, meningkatnya suhu reaksi, waktu reaksi dan rasio mol reaktan. Kondisi optimum yang diperoleh adalah 0,3 mol katalis $\mathrm{NaOH} / \mathrm{kg}$ minyak, suhu $50{ }^{\circ} \mathrm{C}$, waktu reaksi 30 menit dan rasio mol reaktan 1:6, dengan penurunan tegangan permukaan air 29,58 dyne $/ \mathrm{cm}$.

\section{Daftar Pustaka}

Arbianti, R.; Utami, T. S.; Astri, N., Isolasi Metil Laurat dari Minyak Kelapa Sebagai Bahan Baku Surfaktan Fatty Alcohol Sulfate (FAS), Makara Seri Teknologi, 2008, Vol. 12(2), 61-64.

Goenadi, D. H., Prospek dan Arah Pengembangan Agribisnis Kelapa Sawit di Indonesia, Badan Penelitian dan Pengembangan Pertanian, Departemen Pertanian Republik Indonesia, 2005.

Ketaren, S., Minyak dan Lemak Pangan, Penerbit Universitas Indonesia, Jakarta, 1986.

May, C. Y., Transesterification of Palm Oil: Effect of Reaction Parameters, Journal of Oil Palm Research, 2004, Vol. 16(2), 1-11.

Nakamura, M., Fatty Acid Methyl Ester and Its Relative Products from Palm Oil, Journal Oleo Science, 2001, Vol. 50(5), 445-452.

Noureddini, H.; Zhu, D., Kinetics of transesterification of soybean oil, Journal of American Chemical Society, 1997, 74(11), 1457-1463. 